\title{
Evaluating the quality stability of black vinegar-based salad sauce during storage
}

\author{
Minji Choi ${ }^{1}$, Yunhee $\mathrm{Jo}^{1}$, Narae Kim ${ }^{1}$, Chaeeun Bang ${ }^{1}$, Changse Byeon ${ }^{1}$, \\ Hyunsoo Lee ${ }^{1}$, Yang-Ho Jin ${ }^{2}$, Yong-Jin Jeong ${ }^{3}$, Joong-Ho Kwon ${ }^{1 *}$ \\ ${ }^{1}$ School of Food Science and Biotechnology and Food Bio-industry Research Institute, Kyungpook National University, \\ Daegu 41566, Korea \\ ${ }^{2}$ Deptment of Food Service and Culinary, Kyonggi University, Seoul 03746, Korea \\ ${ }^{3}$ Deptment Food Science and Technology, Keimyung University and KMF Co., Daegu 42403, Korea
}

\section{현미흑초 기반 샐러드 소스의 저장 중 품질안정성 평가}

\author{
최민지 ${ }^{1} \cdot$ 조윤희 $^{1} \cdot$ 김나래 ${ }^{1} \cdot$ 방채은 $^{1} \cdot$ 변창세 $^{1} \cdot$ 이현수 $^{1} \cdot$ 진양호 $^{2} \cdot$ 정용진 ${ }^{3} \cdot$ 권중호 $^{1 *}$ \\ ${ }^{1}$ 경북대학교 식품공학부 및 식품생물산업연구소, ${ }^{2}$ 경기대학교 외식조리과학과, \\ 3 계명대학교 식품가공학과 및 (주KMF
}

\begin{abstract}
Microbiological and physicochemical qualities of salad sauce prepared with naturally fermented brown rice black vinegar and citrus juice were evaluated during storage at low $\left(4^{\circ} \mathrm{C}\right)$ and room $\left(20^{\circ} \mathrm{C}\right)$ temperature for 3 months. No bacteria and coliforms were identified in sterilized sauce samples $\left(85^{\circ} \mathrm{C}, 20 \mathrm{~min}\right)$ stored for 3 months, which meets the requirements of the Korean Food Standard Code. The pH and titratable acidity increased significantly over 3 months of storage, 2.89-3.25 and 1.55-2.39\%, respectively, but no deterioration was observed. The Hunter's color yellowness (b value) of stored samples decreased significantly, leading to increments in the overall color difference $(\Delta E)$ with storage time. The viscosity did not significantly change during storage at low temperature for 3 months, and emulsion stability was also maintained at over $92 \%$ when stored for 3 months at low temperature. The peroxide and TBA values increased during storage but satisfied with the fatty-foods standard. Salad sauce sterilized at $85^{\circ} \mathrm{C}$ for 20 min exhibited acceptable quality stability over 3 months at low temperature in terms of microbial levels, viscosity, emulsion stability, peroxide and TBA values, demonstrating its possible use in vinegar-based salad sauce.
\end{abstract}

Key words : salad sauce, black vinegar, viscosity, emulsion, peroxide value

\section{서 론}

식초는 제조방법에 따라 알코올발효 및 초산발효 과정을 거치는 발효식초와, 빙초산을 희석하여 제조하는 합성식초 로 구분된다 $(1,2)$. 최근 곡물과 과일을 자연 발효한 다양한

*Corresponding author. E-mail : jhkwon@knu.ac.kr Phone : 82-53-950-5775, Fax : 82-53-950-6772

Received 28 January 2019; Revised 06 March 2019; Accepted 08 March 2019.

Copyright (c) The Korean Society of Food Preservation. All rights reserved.
종류의 천연발효식초가 생산되고 있으며, 이들 제품은 유 기산과 아미노산의 함량, 향기성분의 조성 및 관능적 품질 이 기존 식초에 비해 우수하고 $(3,4)$, 식욕 증진, 소화흡수 증진, 콜레스테롤 저하, 동맥경화 및 고혈압의 예방, 면역기 능 향상 등 생리활성기능이 다양하여(5-7), 그 소비가 꾸준 히 증가하고 있다. 이와 같이 식초의 여러 가지 효능이 과학 적으로 규명되면서, 천연발효식초는 단순한 조미 용도뿐만 아니라 기능성 소재로도 관심이 높아지고 있다(8). 소스 (sauce)는 조미식품 유형 중 하나인 소스류에 해당하며, 재 료 본래의 맛과 향을 유지하면서 제품의 풍미를 돋우어 관능적 특성을 증진시키는 데 중요한 역할을 한다. 식품공 
전(9)에 의하면 소스는 동·식물성 원료에 향신료, 장류, 당 류, 식염, 식초 등을 첨가하여 혼합한 것이거나 또는 이를 발효·숙성시킨 것으로서, 식품을 제조가공/조리함에 있어 풍미증진을 목적으로 사용되는 것을 말한다(10). 최근 식생 활의 서구화와 건강식에 대한 관심의 증대로 샐러드의 소비 가 증가하고 있다(11). 특히 현미흑초는 아미노산과 무기질 함량이 높고 다이어트에도 도움이 될 수 있다는 보고가 있다(12). 또한 천연발효식초는 재료의 독특한 풍미와 더불 어 저염 및 기능성 효과를 부여할 수 있는 소스의 개발이 가능하였다고 알려져 있다(13). 현재 고품질의 위생적인 샐러드소스 제품에 대한 소비자 선호도의 증가로 인해 업체 에서는 유기농 원료제품 출시, 프리미엄 상품라인 구축 등 으로 대응하고 있다. 국내에서 새로운 소스 개발연구에서 고춧가루(14), 사과(15), 캐슈(16) 등을 기반으로 한 소스류 의 품질특성과 항산화활성(17) 평가를 통해 기능성을 부여 하고자 하였다. 또한 복분자즙 소스(10), 삼백초 요구르트 소스(18), 키위 소스(19) 등의 연구와 같이 다양한 원료를 이용한 혼합비율 및 제조법 표준화 등으로 샐러드소스 제품 개발 연구가 진행되었으나, 현미흑초를 활용한 샐러드소스 개발 연구는 거의 없는 실정이다. 따라서 본 연구에서는 천연발효 현미흑초를 기반으로 한 샐러드소스를 개발할 목적에서, 식초의 강한 신맛을 마스킹 하고자 오렌지와 레 몬주스를 부재료로 사용하여 샐러드소스에 단맛과 풍미를 증진시키고자 하였다(20). 따라서 예비실험을 통해 가장 양호한 최종 원료와 배합비율로 제조한 현미흑초 기반 샐러 드소스를 대상으로, 저장 중 미생물 생육 여부와 이화학적 품질안정성을 모니터링 함으로써 천연발효 현미흑초 기반 샐러드소스의 개발 가능성을 제시하고자 하였다.

\section{재료 및 방법}

\section{실험재료 및 저장}

식초를 기반으로 한 샐러드소스를 제조하고자 천연발효 식초는 (주K(Daegu, Korea)의 현미흑초(산도 5.2\%)를 사용 하였고, 그 외 오렌지주스, 레몬주스, 올리브오일, 꿀 등의 재료는 대형마트에서 구입하여 사용하였다. 식초의 강한 신맛을 마스킹 하고자 시트러스 부재료를 사용함으로써 샐러드소스에 단맛과 풍미를 증진시키고자 하였으며, 이때 전처리 방법과 재료 비율은 선행연구 $(21,22)$ 를 참조하여 여러 차례의 예비실험을 통해 가장 우수한 샐러드소스의 최종 원료 및 배합 비율을 결정하였다(Table 1). 완성된 소스 는 $300 \mathrm{~g}$ 용량의 유리병 12 병에 주입한 후 살균 $\left(85^{\circ} \mathrm{C}, 20\right.$ 분) 및 냉각하였다. 시판 샐러드소스의 유통기한이 냉장(0-1 $0^{\circ} \mathrm{C}$ ) 상태에서 3 개월임을 고려하여, 흑초기반 샐러드소스 를 $4^{\circ} \mathrm{C}$ 냉장 및 $20^{\circ} \mathrm{C}$ 실온의 암실에서 3 개월 간 저장하면서 품질안정성을 분석하였다.
Table 1. Ingredients of salad sauce based on black vinegar

\begin{tabular}{cc}
\hline Ingredient & Content $(\mathrm{g})$ \\
\hline Black vinegar & 60 \\
Orange juice & 100 \\
Lemon juice & 40 \\
Olive oil & 66 \\
Honey & 40 \\
Orange zest & 20 \\
Salt & 4 \\
Pepper & 1 \\
\hline
\end{tabular}

\section{미생물 검사}

소스의 미생물적 품질 분석을 위해 시료 $5 \mathrm{~g}$ 을 멸균된 펩톤수 $45 \mathrm{~mL}$ 로 균질화하고, 총세균과 대장균군 실험에 사용하였다. 총세균은 APHA 표준방법(23)에 따라 plate count agar(Difco Lab, Sparks, MD, USA)를 사용하여 $35^{\circ} \mathrm{C}$ 에 서 24-48시간 배양한 후 생성된 집락을 계수하였다. 대장균 군은 desoxycholate agar(Difco Lab)를 사용하여 $35^{\circ} \mathrm{C}$ 에서 24-48시간 배양한 후 생성된 적색의 집락을 계수하였다. 시료의 미생물 농도는 $\mathrm{CFU} / \mathrm{g}$ 으로 나타내었다.

\section{총산 함량 및 기계적 색도 측정}

시료 $5 \mathrm{~g}$ 에 증류수 $45 \mathrm{~mL}$ 를 가하고 $3,000 \mathrm{rpm}$ 에서 15 분간 원심분리한 후 상층액을 시료로 사용하였다. 총산 함 량은 $0.1 \mathrm{~N} \mathrm{NaOH}$ 용액으로 $\mathrm{pH} 8.34$ 까지 적정하여 초산 함량(\%)으로 나타내었다. 기계적 색도는 색차계(CR-200, Minolta, Osaka, Japan)를 이용하여 명도(L 값, white +100 $\leftrightarrow 0$ black), 적색도(a 값, red $+100 \leftrightarrow 0 \leftrightarrow-80$ green) 및 황색도(b 값, yellow $+70 \leftrightarrow 0 \leftrightarrow-80$ blue)를 측정하였고, 전반적 색차 $(\Delta \mathrm{E})$ 값을 계산하였다.

\section{점도 및 유화안정성 측정}

시료 $50 \mathrm{~g}$ 을 비커에 계량하고 $10^{\circ} \mathrm{C}$ 항온기에서 1 시간 동안 안정화 후 점도계(DV- П, Brookfield, Middleboro, MA, USA)의 No.6 Spindle을 사용하여 $60 \mathrm{rpm}$ 조건에서 1분 동안 측정하였다. 유화안정성(emulsification stability, $\mathrm{ES}$ )은 샐러 드소스를 $20 \mathrm{mesh}$ 체로 여과한 후 약 $10 \mathrm{~g}$ 을 3,000 $\mathrm{pm}$ 에서 10 분간 원심분리하고 분리된 유상의 무게를 측정하였으 며, 아래 식을 이용하여 비율을 산출하였다(24). 이 때 T는 emulsion 전량, $\mathrm{X}$ 는 분리된 유상의 용량을 의미한다.

$$
\mathrm{ES}(\%)=\frac{(0.5 \mathrm{~T}-\mathrm{X})}{0.5 \mathrm{~T}} \times 100
$$

\section{유지 추출}

시료 $10 \mathrm{~g}$ 에 에테르 $50 \mathrm{~mL}$ 를 첨가한 후 2시간 동안 방치 
한 후 여과하였다. 증류수 $25 \mathrm{~mL}$ 를 첨가하여 에테르층을 분리한 후 무수황산을 사용하여 탈수하였으며, $40^{\circ} \mathrm{C}$ 에서 농축하여 실험에 사용하였다.

\section{과산화물가 측정}

시료의 과산화물가(peroxide value, $\mathrm{POV}$ ) 측정은 $\mathrm{AOAC}$ 방법(25)에 따라 추출된 유지 $0.5 \mathrm{~g}$ 에 초산과 클로로포름의 혼합액(3:2) $10 \mathrm{~mL}$ 를 첨가한 후 포화요오드화칼륨용액 1 $\mathrm{mL}$ 를 가하여 암실에서 10 분간 방치하였다. 증류수 $30 \mathrm{~mL}$ 를 첨가하여 잘 흔들어 준 후 $1 \%$ 전분지시약을 가하고 $0.01 \mathrm{~N}$ 티오황산나트륨용액으로 적정하였다.

\section{TBA가 측정}

시료의 thiobarbituric acid(TBA)가를 측정하기 위해 추출 된 유지 $1 \mathrm{~g}$ 에 벤젠 $5 \mathrm{~mL}$ 와 $20 \% \mathrm{TBA}$ 용액 $5 \mathrm{~mL}$ 를 가한 후 실온에서 4 분간 방치하였다. 분액깔때기로 분리된 물 층을 $90^{\circ} \mathrm{C}$ 에서 30 분간 가열한 후 분광광도계(Optizen 2021UV, Mecasys Co., Ltd., Daejeon, Korea)를 이용하여 $530 \mathrm{~nm}$ 에서 흡광도를 측정하였고, 시료의 TBA가는 $\mathrm{mg}$ malonaldehyde equivalent(MA) $/ \mathrm{kg}$ 으로 나타내었다.

\section{통계처리}

모든 실험은 3회 반복하여 그 결과를 평균과 표준편차로 나타내었고, statistical analysis system software(SAS version 8.1, SAS Institute, Cary, NC, USA)를 이용하여 분산분석 및 Duncan's multiple range test로 유의차를 검정하였다 $(26)(\mathrm{p}<0.05)$.

\section{결과 및 고찰}

\section{미생물적 품질안정성 평가}

식품의 생산·가공·유통 과정에서 위생상태 및 분변오염 의 지표로 사용되는 총세균과 대장균군의 확인을 위해, 샐 러드소스 살균 시료의 저장에 따른 미생물학적 품질 변화를 관찰하였다. 총세균은 제조 직후 음성으로 확인되었고, $4^{\circ} \mathrm{C}$ 및 $20^{\circ} \mathrm{C}$ 조건에서 저장 3 개월 동안 시료에서 검출되지 아니 하여 본 흑초기반 샐러드소스 시제품은 미생물적으로 안정 함을 확인하였다. 식품공전(27)에서 소스류의 세균수 기준 은 멸균제품에 한해 $n=5, c=0, m=0$ 로 규정되어 있다. 시료 의 대장균군 역시 냉장 및 실온저장 조건에서 3 개월 동안 음성으로 확인되었으며, 이는 소스류는 대장균군이 음성이 어야 한다는 식품공전의 기준 $(\mathrm{n}=5, \mathrm{c}=1, \mathrm{~m}=0, \mathrm{M}=10)$ 을 만 족하였다(data not shown). 살균된 샐러드소스의 저장 중 미생물학적 안전성은 스피루리나 소스(28) 및 데리아끼 소 스(29)에서 유사한 결과가 보고되었다. 이상의 결과, 흑초 기반 샐러드소스는 $85^{\circ} \mathrm{C}$ 에서 20 분의 열탕조건으로 살균이
가능하여 $4-20^{\circ} \mathrm{C}$ 온도 범위에서 저장 3 개월 동안 미생물적 품질안정성을 확인하였다.

\section{총산 함량 변화}

샐러드소스의 총산 함량 변화는 Table 2 와 같다. 저장 초기 총산 함량은 $1.55 \pm 0.12 \%$ 수준이었고, 저장 1 개월에는 $1.50-1.56 \%$ 수준으로 큰 변화를 보이지 않았다. 저장 2개월 및 3개월에는 각각 1.91-1.95 및 2.03-2.39\% 수준으로 유의 적인 증가를 나타내었으나 $(\mathrm{p}<0.05)$, 그 변화 폭이 크지 않았 다. 즉, 샐러드소스의 총산 함량 역시 저장온도보다 저장기 간에 영향을 받아 증가하는 경향을 나타내었다. 식품의 산 도는 저장성을 나타내는 지표로써 저장기간이 길어질수록 미생물이 생성하는 산의 증가로 인해 산도가 증가하게 된다 (30). 본 연구의 샐러드소스는 냉장 및 실온저장 중 $4-20^{\circ} \mathrm{C}$ 조건에서 저장 3 개월 동안 비교적 안정한 수준의 산도변화 를 나타내었다.

Table 2. Changes in titratable acidity of salad sauce based on black vinegar during storage

\begin{tabular}{ccccc}
\hline \multirow{2}{*}{$\begin{array}{c}\text { Storage temp. } \\
\left({ }^{\circ} \mathrm{C}\right)\end{array}$} & 0 & 1 & 2 & 3 \\
\cline { 2 - 5 } & 0 & \multicolumn{4}{c}{ Storage period (month) } \\
\hline 4 & $1.55 \pm 0.12^{1) \mathrm{Ba} 2)}$ & $1.50 \pm 0.15^{\mathrm{Ba}}$ & $1.91 \pm 0.10^{\mathrm{Aa}}$ & $2.03 \pm 0.04^{\mathrm{Ab}}$ \\
20 & $1.55 \pm 0.12^{\mathrm{Ca}}$ & $1.56 \pm 0.13^{\mathrm{Ca}}$ & $1.95 \pm 0.15^{\mathrm{Ba}}$ & $2.39 \pm 0.29^{\mathrm{Aa}}$ \\
\hline
\end{tabular}

${ }^{1)}$ Values are Mean \pm SD of triplicate determinations.

${ }^{2)}$ Values followed by different uppercase letters (A-C) within a row and by different lowercase letters $(a-b)$ within a column are significantly different at $p<0.05$ based on Duncan's multiple range test.

\section{기계적 색도 변화}

샐러드소스의 기계적 색도 측정 결과는 Table 3에 나타내 었다. 저장 중 시료의 명도(L 값)는 40.14-43.69 범위로 저장 기간에 따라 유의적으로 증가하였으며 $(\mathrm{p}<0.05)$, 온도에 따 른 차이는 보이지 않았다. 적색도(a 값)는 저장온도가 높아 지고 저장기간이 증가할수록 -1.50 에서 1.09 까지 유의적으 로 증가하였다 $(\mathrm{p}<0.05)$. 한편, 황색도 $(\mathrm{b}$ 값 $)$ 는 저장 초기 29.55 \pm 1.29 수준에서 저장 3개월 째 12.14-12.54 범위까지 유의적으로 감소하는 경향을 보였다 $(\mathrm{p}<0.05)$. 이 같은 결과 는 생마즙과 오디첨가 소스 연구에서 저장기간이 길어질수 록 황색도 값이 감소하였다는 보고와 유사한 경향이었다 $(31,32)$.

이상의 기계적 색도 변화를 바탕으로 한 전반적 색도 $(\Delta \mathrm{E})$ 는 저장 온도와 기간의 변화에 따라 유의적으로 증가하여 $(\mathrm{p}<0.05)$ 저장 3 개월 후에는 17.43-18.02 범위로 확인되었으 며, 이는 흑초기반 샐러드소스의 색도 변화가 기호적 품질 과 어떤 상관성을 나타내는지 추가적인 연구가 요망되었 다. 
Table 3. Changes in Hunter's color value of salad sauce based on black vinegar during storage

\begin{tabular}{cccccc}
\hline \multirow{2}{*}{$\begin{array}{c}\text { Hunter's } \\
\text { color value }\end{array}$} & Storage temp. $\left({ }^{\circ} \mathrm{C}\right)$ & \multicolumn{4}{c}{ Storage period (month) } \\
\cline { 3 - 6 } & & 0 & 1 & 2 & 3 \\
\hline $\mathrm{L}$ & 4 & $40.14 \pm 0.86^{1) \mathrm{Ca} 2)}$ & $42.64 \pm 0.98^{\mathrm{ABa}}$ & $41.64 \pm 0.94^{\mathrm{Bb}}$ & $43.39 \pm 1.75^{\mathrm{Aa}}$ \\
& 20 & $40.14 \pm 0.86^{\mathrm{Ba}}$ & $40.91 \pm 1.14^{\mathrm{Bb}}$ & $42.99 \pm 1.20^{\mathrm{Aa}}$ & $43.69 \pm 1.09^{\mathrm{Aa}}$ \\
\hline $\mathrm{a}$ & 4 & $-1.50 \pm 0.73^{\mathrm{BCa}}$ & $-1.02 \pm 1.29^{\mathrm{ABb}}$ & $-1.89 \pm 0.37^{\mathrm{Cb}}$ & $-0.43 \pm 0.47^{\mathrm{Ab}}$ \\
& 20 & $-1.50 \pm 0.73^{\mathrm{Ca}}$ & $0.07 \pm 0.57^{\mathrm{Ba}}$ & $0.20 \pm 0.81^{\mathrm{Ba}}$ & $1.09 \pm 0.93^{\mathrm{Aa}}$ \\
\hline $\mathrm{b}$ & 4 & $29.55 \pm 1.29^{\mathrm{Aa}}$ & $25.98 \pm 3.11^{\mathrm{Bb}}$ & $16.24 \pm 1.31^{\mathrm{Cb}}$ & $12.54 \pm 1.36^{\mathrm{Da}}$ \\
& 20 & $29.55 \pm 1.29^{\mathrm{Aa}}$ & $30.33 \pm 0.54^{\mathrm{Aa}}$ & $18.65 \pm 2.34^{\mathrm{Ba}}$ & $12.14 \pm 0.64^{\mathrm{Ca}}$ \\
\hline$\Delta \mathrm{E}$ & 4 & $0.00 \pm 0.00^{\mathrm{Da}}$ & $5.19 \pm 1.95^{\mathrm{Ca}}$ & $13.45 \pm 1.22^{\mathrm{Ba}}$ & $17.43 \pm 1.46^{\mathrm{Aa}}$ \\
& 20 & $0.00 \pm 0.00^{\mathrm{Da}}$ & $2.23 \pm 0.67^{\mathrm{Cb}}$ & $11.48 \pm 2.32^{\mathrm{Bb}}$ & $18.02 \pm 0.53^{\mathrm{Aa}}$ \\
\hline
\end{tabular}

${ }^{1)}$ Values are Mean $\pm \mathrm{SD}$ of triplicate determinations.

${ }^{2)}$ Values followed by different uppercase letters (A-D) within a row and by different lowercase letters (a-b) within a column are significantly different at $p<0.05$ based on Duncan's multiple range test.

\section{점도 및 유화안정성 변화}

샐러드소스의 저장에 따른 점도 측정 결과는 Fig. $1 \mathrm{~A}$ 와 같으며, 시료의 점도는 저장 초기 $143 \pm 25 \mathrm{cP}$ 수준이었다.

(A)

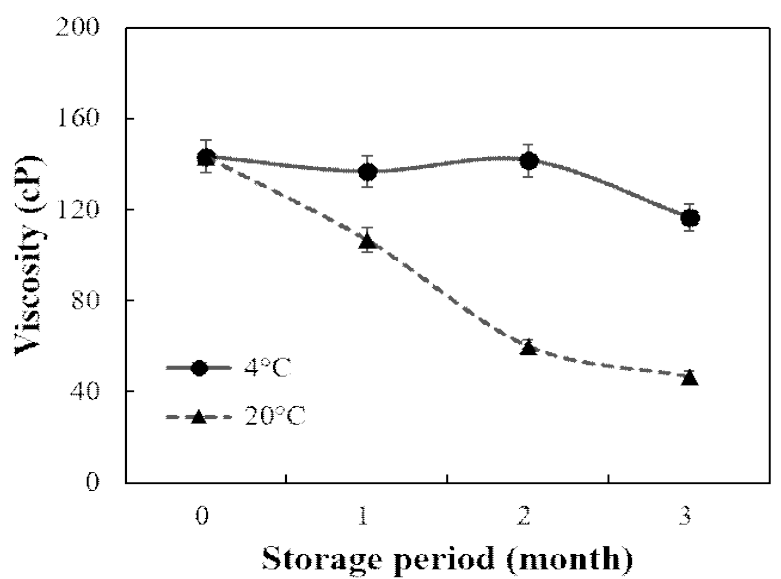

(C)

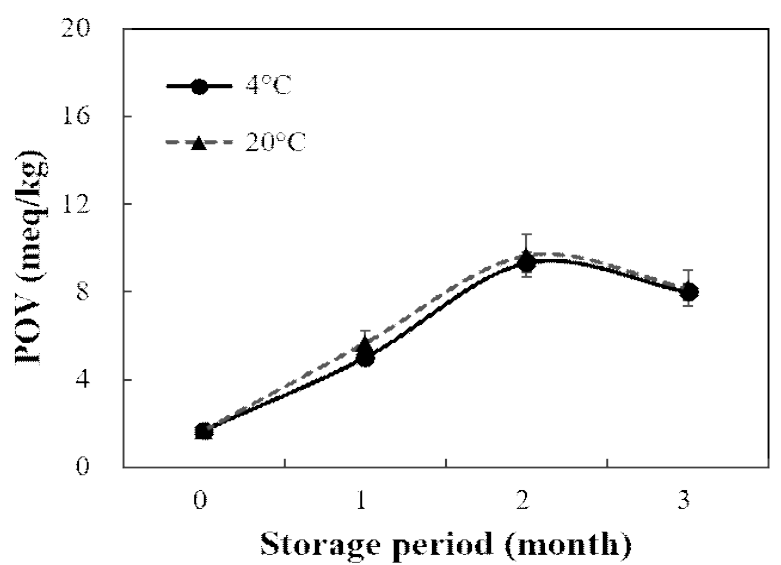

올리브유와 식초가 함유된 프렌치드레싱 소스의 점도는 본 연구에서와 유사한 경향을 보여주었으나(33), 마요네즈 가 첨가된 샐러드소스의 경우 점도가 $170,000 \mathrm{cP}$ 수준을

(B)

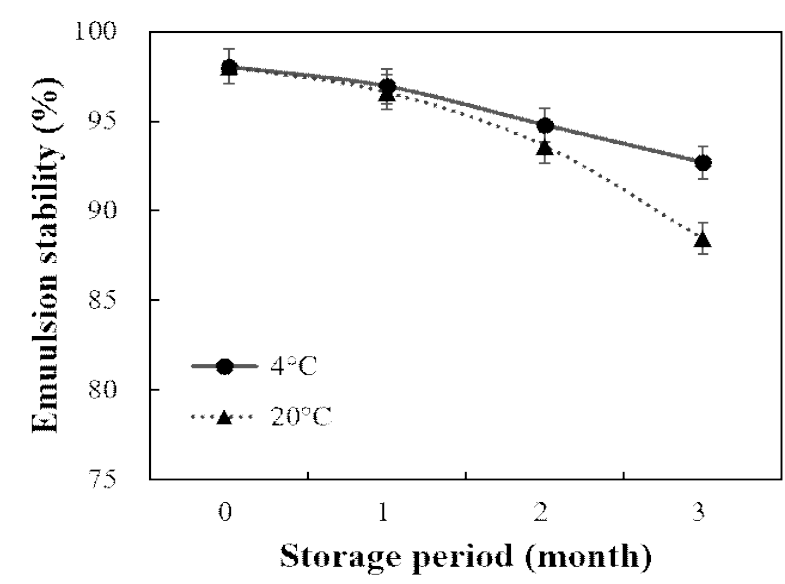

(D)

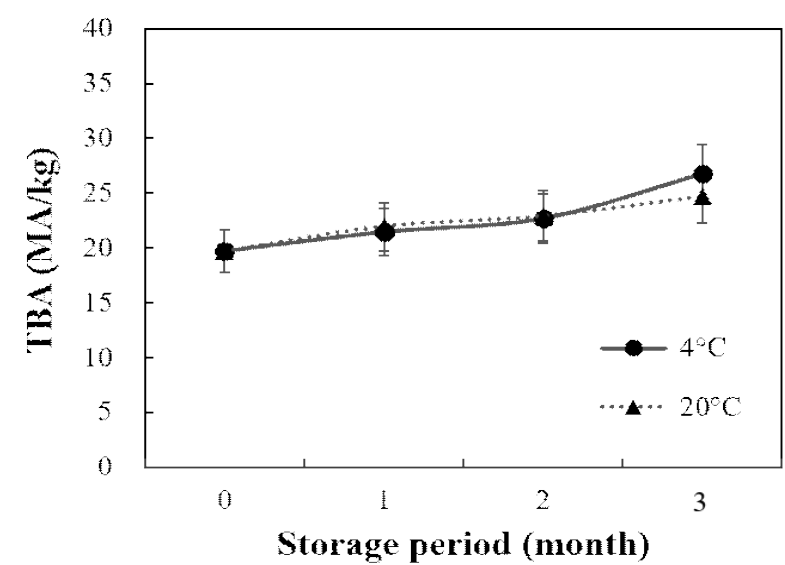

Fig. 1. Changes in viscosity (A), emulsion stability (B), POV (C), and TBA (D) of salad sauce based on black vinegar during storage. 
나타내어(34), 원료 및 제조방법에 따른 최종제품의 점도 차이를 보여주었다. 시료의 저장에 따른 점도 측정 결과, $4^{\circ} \mathrm{C}$ 저장시료는 3 개월 동안 $117-142 \mathrm{cP}$ 수준으로 안정적인 값을 보여주었다. 이는 된장샐러드소스의 5 및 $10^{\circ} \mathrm{C}$ 냉장저 장 중 점도는 유의적인 변화를 보이지 않았다는 보고와 유사한 경향이었다(35). 한편, $20^{\circ} \mathrm{C}$ 저장시료의 점도는 저장 1 개월 및 3 개월에 각각 $107 \pm 9 \mathrm{cp}$ 및 $47 \pm 8 \mathrm{cp}$ 수준으로 저장 초기 대비 약 $65 \%$ 수준까지 큰 폭으로 감소하였고 $(\mathrm{p}<0.05)$, 샐러드소스의 점도는 실온 조건에서는 영향을 받 는 것으로 확인되었다. 이상의 결과, 흑초기반 샐러드소스 는 냉장유통 조건인 $4^{\circ} \mathrm{C}$ 에서 저장 3 개월까지 초기 점도가 안정적으로 유지됨을 확인할 수 있었다.

샐러드소스의 저장에 따른 유화안정성 변화는 Fig. $1 \mathrm{~B}$ 와 같다. 소스시료의 제조 직후 유화안정성은 $98.06 \%$ 로 나타 났으며, $4^{\circ} \mathrm{C}$ 조건에서는 저장 3 개월까지 $92.69-96.97 \%$ 수준 까지, $20^{\circ} \mathrm{C}$ 조건에서는 $88.44-96.63 \%$ 수준까지 유의적인 감소를 보여주었다 $(\mathrm{p}<0.05)$. 즉, 샐러드소스의 유화안정성 은 저장온도와 저장기간에 영향을 받아 감소하였으나, 냉 장 조건인 $4^{\circ} \mathrm{C}$ 에서 안정성이 보다 유지되었다. 유화식품의 경우 품질 유지를 위해 유화안정성이 중요하며, 이는 온도 변화, 지방구의 입도 분포 등 여러 가지 조건에 영향을 받는 다 $(36,37)$. 마요네즈의 경우 유화안정성은 $90 \%$ 이상으로 알려져 있으며 $(38,39)$, 본 실험의 샐러드소스 또한 저장 $\left(4^{\circ} \mathrm{C}\right) 3$ 개월까지 $92 \%$ 이상의 유화안정성을 유지하는 경향 성을 보였다.

\section{과산화물가(POV) 및 TBA가 변화}

과산화물가는 기름의 자동산화 초기에 생성되는 과산화 물의 함량을 측정하여 기름의 초기 산패 정도를 확인할 수 있는 지표로, 샐러드소스의 과산화물가 변화는 Fig. 1C 와 같다. 샐러드소스의 제조 직후 과산화물가는 $1.67 \pm 1.15$ $\mathrm{meq} / \mathrm{kg}$ 수준으로 이는 Kim 등(40)이 연구한 샐러드드레싱 의 초기 과산화물가 $1.12-1.51 \mathrm{meq} / \mathrm{kg}$ 와 유사한 수준으로 확인되었다. 한편, 냉장 및 실온저장 후 과산화물가는 저장 1 개월과 2개월에 각각 $5.00-5.67 \mathrm{meq} / \mathrm{kg}$ 및 9.33-9.67 $\mathrm{meq} / \mathrm{kg}$ 범위로 유의적인 증가를 나타내었고 $(\mathrm{p}<0.05)$, 저장 3 개월에는 8.17-8.00 meq/kg 수준으로 큰 변화를 보이지 않았다. 일반적으로 과산화물가는 $10 \mathrm{meq} / \mathrm{kg}$ 이하이면 신 선한 기름으로 간주하고(41), $30 \mathrm{meg} / \mathrm{kg}$ 이상인 유지는 독 성을 가질 가능성이 있다고 알려져 식용유지로 사용하지 않는다(42). 시판 소스에 사용되는 주재료인 식용유지는 식물성 정제 기름으로 산소, 온도, 효소, 미생물, 금속, 재료 의 종류 또는 수분함량에 따라 쉽게 산패되는 것으로 보고 되고 있다(43). 국내에서는 차조기(44), 녹차(45), 된장(35) 등의 재료를 첨가하여 소스의 자동산화를 억제시키는 연구 가 보고된 바 있다. 이상의 결과, 샐러드소스의 과산화물가 는 저장 기간에 따라 다소 증가하였으나, 유지식품의 과산
화물가 기준(41)을 만족하는 수준이었다.

유지식품은 산패가 진행됨에 따라 지방산화 2차 생성물 인 malonaldehyde가 생성되어 적자색의 복합체를 형성하게 되는데(46), TBA가는 이와 같은 현상으로 유지식품의 산패 도 및 산화에 대한 저항성 등을 측정할 수 있다. 샐러드소스 의 초기 TBA가는 $19.70 \pm 2.00 \mathrm{MA} / \mathrm{kg}$ 수준이었고, 저장 1 개 월에 21.46-21.96 MA/kg, 2개월에 22.70-22.90 MA/kg, 3개 월에 24.70-26.80 MA/kg 범위로 점차 증가하는 경향이었다 (Fig. 1D). 이 같은 경향은 된장샐러드소스(35)의 품질 측정 에서 저장 중 지질산패도가 증가하였다는 보고와 유사하였 으나, 스피루리나 첨가 소스(28)의 경우 저장온도가 높을수 록 시료의 TBA 값이 증가하였다는 보고와는 다소 상이한 결과였지만 저장 3 개월째에는 차이가 확인되었다.

\section{요 약}

천연발효 현미흑초 기반의 샐러드소스를 제조하여 열탕 $\left(85^{\circ} \mathrm{C}, 20\right.$ 분 $)$ 으로 살균한 시제품을 저온 $\left(4^{\circ} \mathrm{C}\right)$ 과 상온 $\left(20^{\circ} \mathrm{C}\right)$ 에 3개월 간 저장하면서 미생물학적 및 이화학적 품질안정 성을 분석하였다. 시료의 총 세균과 대장균군은 저장 3 개월 동안 음성으로 확인되어 소스류의 식품공전기준을 만족하 였다. 총산 함량은 저장 3개월 동안 2.89-3.25 및 1.55-2.39\% 범위로 유의적인 증가를 보였으나 $(\mathrm{p}<0.05)$, 변질로 의심되 는 변화는 관찰되지 않았다. 시료의 기계적 색도에서 황색 도(b 값)는 저장 중 유의적으로 감소하여 전반적 색차 $(\Delta \mathrm{E})$ 는 증가하였다 $(\mathrm{p}<0.05)$. 점도는 저온저장 3 개월 동안 유의 적 차이를 보이지 않았고, 유화안정성 또한 저온저장 3개월 간 $92 \%$ 이상의 안정성을 유지하였다. 샐러드소스의 과산화 물가와 TBA가는 3개월 저장 중 다소 증가하였으나, 유지식 품의 기준을 만족하는 수준이었다. 이상의 결과, 천연발효 현미흑초를 기반으로 제조한 샐러드소스는 미생물의 생육 이 관찰되지 않았고 점도, 유화안정성, 과산화물가 및 TBA 가는 저온저장 3 개월 동안 안정한 수준을 유지하여 새로운 개념의 흑초기반 샐러드소스 개발 가능성을 시사하였다.

\section{References}

1. Ha YD, Kim KS (2000) Civilization history of vinegar. Food Industry and Nutrition, 5, 1-6

2. Jeong YJ, Lee MH (2000) A view and prospect of vinegar industry. Food Industry and Nutrition, 5, 7-12

3. Shim GS (1984) The metabolism and health of vinegar. Korean J Food Sci Technol, 17, 5-9

4. Yoon HN (1999) Chemical characterization of commercial vinegars. Korean J Food Sci Technol, 31, 
$1440-1446$

5. Yukirnichi K, Yasuhiro U, Fujiharu Y (1987) The general composition inorganic cations free amino acids and organic acid of special vinegars. Nippon Shokuhin Kogyo Gakkaishi, 34, 592-596

6. Vogel RA, Corretti MC, Plotnick GD (2000) The postprandial effect of components of the mediterranean diet on endothelial function. J Am Coll Cardiol, 36, 1455-1460

7. Casale M, Saiz AMJ, Gonzalez SJM, Pizarro C, Forina M (2006) Study of the aging and oxidation processes of vinegar samples from different origins during storage by near-infrared spectroscopy. Anal Chim Acta, 557, 360-366

8. Kwon SH, Jeong EJ, Lee GD, Jeong YJ (2000) Preparation method of fruit vinegars by two stage fermentation and beverages including vinegar. Food Industry and Nutrition. 5, 18-24

9. Ministry of Food and Drug Safety (2018) Korea Food Code. Ministry of Food and Drug Safety, Osong, Korea, p 141

10. Jung SJ, Kim NA, Jang MS (2008) Formulation optimization of salad dressing added with Bokbunja (Rubus coreanum Miquel) Juice. J Korean Soc Food Sci, 37, 497-504

11. Kim SN, Koo HJ, Kim KS, Park JB (2006) Characteristics of Korean single-harvested pepper (Capsicum annuum L.) flakes and the effects on the quality of various dressings. Korean J Food Cookery Sci, 22, 12-21

12. Chou CH, Liu CW, Yang DJ, Samuel Wu YH, Chen YC (2015) Amino acid, mineral, and polyphenolic profiles of black vinegar, and its lipid lowering and antioxidant effects in vivo. Food Chem, 168, 63-69

13. Jeong YJ, Jin YH, Kwon JH, Han SJ, Jung DA, Kim SH (2018) Industralization Process building up of Naturally Fermented Vinegar using Domestic Agricultural Resource and Sauce Development for Export. Final Report, Ministry of Agriculture Food and Rural Affairs (MAFRA), 314072-3

14. Son MH (2004) A Study on research \& development and quality stability of functional red pepper dressing. Korean J Culinary Research, 10, 107-120

15. Hong JY, Choi YJ, Kim MH, Shin SR (2009) Study on the quality of apple dressing sauce added with pine mushroom (Tricholoma matsutake sing) and chitosan. Korean J Food Preserv, 16, 60-67

16. Choi SN, Chung NY (2009) The quality and sensory characteristics of cashew dressing. Korean J Food Cookery Sci, 25, 39-44

17. Jeong $\mathrm{CH}$, Shin JH, Kang MJ, Seoung TJ, Shim KH, Choi SG (2007) Effect of garlic addition on oxidative stability of oil dressing and mayonnaise. J Agric Life Sci, 41, 55-61

18. Hwangbo MH, Kim HJ, Yu MH, Lee JW, Lee IS (2006) Optimization of dressing preparation from yogurt added Saururus chinensis (Lour.) bail extract. Korean J Food Cookery Sci, 22, 22-29

19. Kim MH, Lee YJ (2002) A study on standardizing a recipe for kiwi salad dressing. J East Asian Soc Dietary Life, 12, 407-414

20. Chae YC (2000) The study of Classification sauces. Journal of Research Ulsan College, 27, 493-505

21. Kim MH, Lee YJ, Kim DS, Kim DH (2003) Quality characteristics of fruits dressing. Korean J Food Cookery Sci, 19, 165-173

22. Cho IS, Jin HH, Lee SJ (2015) A study on the optimization of green kiwi and gold kiwi puree mixing ratio for the best french kiwi dressing. Korean J Culinary Res, 21, 16-28

23. APHA (1992) Compendium of methods for the Microbiological Examination of Foods. $3^{\text {rd }}$ ed, American Public Health Association, Washington DC, USA, p 75

24. Kevin NP, John EK (1978) Emulsifying properties of proteins: evaluation of a turbidimetric technique. J Agric Food Chem, 26, 716-723

25. AOAC (1995) Official methods of analysis. $16^{\text {th }}$ ed, Association of Official Analytical Chemists, Washington DC, USA, p 69-74

26. Gomez KA, Gomez AA (1984) Duncan's Multiple Range Test. Statistical Procedure for Agril Res $2^{\text {nd }}$ ed, A Wiley Inter-Science Publication, Johan and Sons, New York, NY, USA, p 202-215

27. Ministry of Food and Drug Safety (2018) Korean Food code. Ministry of Food and Drug Safety, Osong, Korea, p 23-24

28. Cho H, Yang YH, Lee KJ, Cho YS, Chun HK, Song KB, Kim MR (2005) Quality characteristics of low fat salad dressing with spirulina during storage. Korean $\mathbf{J}$ Food Preserv, 12, 329-335

29. Park HN, Kang OK, Moon WS (2006) Ingredient preservation in the practical manufacture of teriyaki sauce. Korean J Food Cookery Sci, 22, 111-121

30. Lee JS, Kim GN, Jang HD (2008) Effect of red ginseng extract on storage and antioxidant activity of tofu. J 
Korean Food Sci Nutr, 37, 1497-1506

31. Kim CR, Yim SB, Kim HD, Oh HL, Jeon HL, Kim NY, Hong YP, Lee JH, Kim MR (2012) Change in the quality characteristics of salad dressing prepared with mulberry, Schisandra chinensis and yam juice during storage. Korean J Food Preserv, 19, 825-832

32. Jo SK (2008) Quality characteristics of dressing added with mulberry. MS Thesis, Kyonggi University, Korea, p 51

33. Chun JA, Song ES (1995) Sensory and physical properties of low-fat mayonnaise made with starch-based fat replacers. Korean J Food Sci Technol ,27, 839-844

34. Cha GS, Kim JW, Choi CU (1988) A comparison of emulsion stability as affected by egg yolk ratio in mayonnaise preparation. Korean J Food Sci Technol, 20, 225-230

35. Shim HJ, Shon CW, Kim MH, Kang EY, Kim MY, Lee KJ, Lee JH, Kim MR (2008) Antioxidant activity and quality characteristics of soypaste salad dressing stored at two different temperatures. Korean J Food Cookery Sci, 24, 92-98

36. Park GS, Kim JY (2011) Quality characteristics of mayonnaise dressing added with chitooligossaccharide. J Chitin Chitosan, 16, 183-190

37. Yang SC, Han JY (2002) The effect of vinegar concentration the emulsion stability of mayonnaise dressing. Korean J Culinary Research, 8, 295-308

38. Chun JA, Song ES (1995) Sensory and physical properties of low-fat mayonnaise made with starch-based fat replacers. Korean J Food Sci Technol, 27, 839-844
39. Lee MO, Song YS (2003) Manufacture and stability of low calorie mayonnaise using gums. J Korean Soc Food Sci Nutr, 32, 82-88

40. Kim CR, Yim SB, Kim HD, Oh HL, Jeon HL, Kim NY, Hong YP, Lee JH, Kim MR (2012) Change in the quality characteristics of salad dressing prepared with mulberry, Schisandra chinensis and yam juice during storage. Korean J Food Preserv, 19, 825-832

41. Lee YJ, Ryu HS, Chun SS (2010) Quality characteristics of salad dressing prepared with mulberry fruit powder. Korean J Food Cookery Sci, 26, 537-544

42. Feuge RO (1960) Edible Oils in Nutritional Evaluation of Food Processing. John Wiley and Sons Co Inc, New York, NY, USA, p 254-260

43. Okezie IA (1998) Free radicals, oxidative stress and antioxidants in human health and disease. J Am Oil Chem, 75, 199-212

44. Ahn H (2011) Effects of Chajogi (Perilla frutescens) extracts on th quality of vinaigertte dressing during storage. Korean J Culinary Research, 17, 226-237

45. Park CS, Park EJ (2002) Oxidative stability of green tea-added mayonnaise. Korean J Food Cookery Sci, 18, 407-412

46. Bernheim F, Bernheim MLC, Wilbur KM (1948) The reaction between thiobarbituric acid and the oxidation products of certain lipids. J Biol Chem, 174, 257-264 